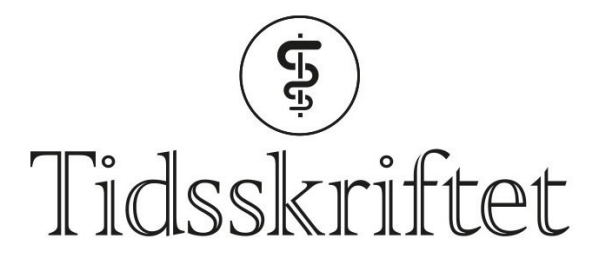

DEN NORSKE LEGEFORENING

\title{
Brit Nyland
}

MINNEORD

KRISTINA HERNBORG JOHANNESSEN

YNGVILD SKÅTUN HANNESTAD

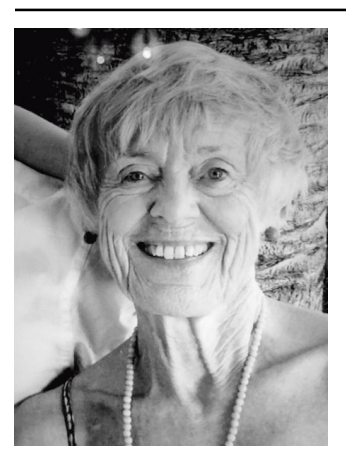

Lege Brit Nyland, f. Omdal, gikk bort 22. januar. Hun var født i Stavanger 16. september 1943 og vokste opp der med foreldrene og søsteren Randi. Etter examen artium studerte hun medisin i Oslo og Bergen. På samme kull møtte hun sin kommende livsledsager Harald, og de giftet seg i 1966. Etter embetseksamen i 1968 reiste de sammen til Hammerfest for turnustjeneste. Etter endt turnustjeneste i distrikt slo de seg ned i Bergen. I perioden 1973-79 var Brit assistentlege/reservelege ved Kvinneklinikken. I 1979 var hun ferdig spesialist i fødselshjelp og kvinnesykdommer og overtok praksisen til Inger Haldorsen, den legendariske kvinnelegen i Bergen. Senere etablerte Brit og en kollega fellespraksis i store lyse lokaler i Bergen sentrum, der de også ansatte jordmødre for svangerskapskontroller.

Hun var faglig aktiv og gjennom mange år styremedlem i Norsk gynekologisk forening og Hordaland legeforening, samtidig som hun sammen med kolleger deltok i nasjonale og internasjonale møter/kongresser. Brit var en meget kunnskapsrik og empatisk lege og var svært godt likt og respektert av så vel pasienter som kolleger. Mange kvinner søkte hennes trygge omsorg og behandling frem til hun pensjonerte seg i 2012. Hun var ikke bare lege, men også en habil kunstner som malte akvareller, oljemalerier og på porselen. Hun utvidet sine kunnskaper og ferdigheter på disse feltene gjennom malerkurs i Bergen og i Spania. Hun var også interessert i blomster og hadde vakre, velstelte hager, både hjemme i Fyllingsdalen og på sommerstedet på Ask. I mange år har hun og Harald hatt hus i Torrevieja, Spania der de ferierte og tilbrakte perioder av pensjonisttiden.

De siste årene var hun rammet av sykdom. Det er et stort savn at Brit er gått bort. Våre tanker går til hennes livsledsager Harald og de tre barna med familier. 
Publisert:30. mars 2020. Tidsskr Nor Legeforen. DOI:10.4045/tidsskr.20.0106 (C) Tidsskrift for Den norske legeforening 2020. Lastet ned fra tidsskriftet.no 